\title{
National Energy Transition Framework toward SDG7 with Legal Reforms and Policy Bundles: The Case of Taiwan and Its Comparison with Japan
}

\author{
Mu-Xing Lin $\left.{ }^{1}{ }^{(}\right)$, Hwa Meei Liou ${ }^{2}$ and Kuei Tien Chou ${ }^{3, *}$ \\ 1 Graduate Institute of National Development, National Taiwan University, Taipei 10617, Taiwan; \\ d03341012@ntu.edu.tw \\ 2 Graduate Institute of Technology Management, National Taiwan University of Science and Technology, \\ Taipei 10607, Taiwan; liouhm@mail.ntust.edu.tw \\ 3 Graduate Institute of National Development, and Risk Society and Policy Research Center, National Taiwan \\ University, Taipei 10617, Taiwan \\ * Correspondence: ktchou@ntu.edu.tw; Tel.: +886-(0)2336-633-28
}

Received: 2 February 2020; Accepted: 12 March 2020; Published: 16 March 2020

check for updates

\begin{abstract}
The main problem explored in this study is how Taiwan and other countries meet the challenges of the United Nations Sustainable Development Goals regarding energy transition by using legal instruments or policy bundles. This study adopts textual analysis and legal policy analysis as its main form of research methodology, and the theory of energy justice, as well as principles of energy management, to correlate with the Sustainable Development Goals. Furthermore, this study aims to construct an analysis structure for national energy transition and to analyze the current situation within Taiwan's electricity sector reforms, while providing evidence of the national experience of electrical industry reforms as an international reference. This study also compares the differences between the seventh Sustainable Development Goal relationship and national energy transitions in Taiwan and Japan, based on the similar initiative of the revised Electricity Act with the policy bundle. This study specifically finds that, firstly, the theory for energy justice is connected with the principles for energy management, owing to the same concepts of "Fair Competition", via the recognition of "Energy Development and Poverty", which correlates with "Environment Protection". Therefore, the concept of energy transition proposed in this study integrates national energy development policy goals and combines them with environmental sustainability, the green economy, and social equity. Secondly, the national energy transition in Taiwan is a response to the Sustainable Development Goals, and electricity sector-related laws could be used as legal tools for national energy transition. This study concludes that Taiwanese and Japanese governments can strengthen their environmental regulations to promote fair competition directly, with fair competition then being able to enhance stable electricity supply, to enable these countries to move towards the seventh Sustainable Development Goal and its indicators. Finally, the analysis structure used in this study could be used as a policy analysis tool for other countries during their own energy transition, when a nation is willing to strategically reform its electricity sector and make sustainable choices regarding transition paths and policy bundles that are suitable for the situation of the individual country. Then, a nation can make revisions to its laws and formulate a policy that is in line with local conditions, while as simultaneously implementing the Sustainable Development Goals.
\end{abstract}

Keywords: sustainable development goals; energy transition; electricity sector; energy justice; sustainable energy 


\section{Introduction}

\subsection{Sustainable Development Goals at the National Level}

The United Nations (UN) adopted the "Transforming our World: The 2030 Agenda for Sustainable Development" as its development agenda, which includes a manifesto called the Sustainable Development Goals (SDGs), as well as related targets and follow up and audit protocols [1,2]. The seventh Sustainable Development Goal (SDG7) aims to ensure that, by 2030, all people have access to affordable, reliable, sustainable and modern energy, which, at a national level, has a concrete meaning in terms of the common development of renewable energy and a significant improvement in energy efficiency. The International Bank for Reconstruction and Development et al. [3] have worked together with the UN Environment Programme (UNEP) to publish annual progress reports on the progress made toward sustainable energy at the international, regional and national levels. Moreover, in terms of SDGs, besides climate change, energy transition is the greatest transitional challenge facing developed countries [4]. Sustainable energy is vital in the efforts to attain these SDGs, as renewable energy could be used in the poorest communities to provide modern energy services [5]. Munro et al. [6] pointed out that, in order for SDG7 to be realized, energy justice needs to be considered, with misgivings over the potential for energy transition to marginalize traditional energy producers and consumers. Energy transition, therefore, needs to emphasize the importance of clear procedures and a political agenda for recognition justice. This study seeks to interpret the concepts of procedural justice $[7,8]$ and recognition justice $[9,10]$ in a Taiwanese context and to propose related energy policies within this context, assuming that the SDG7 not only provides the meaning of energy, but also enables individual countries to respond to the SDG7 by setting goals and making their own policy bundles for national energy transitions, while enabling interactions between the national energy transition goals for each individual country to adjust the timing and priority of their policy bundles in order to reach their goals for national energy transition. Furthermore, the international research community has also launched a well-known and flagship project, called "The World in 2050 (TWI2050)", as a follow up to the SDGs [11]. The report entitled "Transformations to achieve the Sustainable Development Goals" was first prepared by The World in 2050 initiative at the High-Level Political Forum 2018 in New York [12]. Although policy-oriented rather than legally binding, this report integrates the seventeen SDGs into six transformation fields, including "decarbonization and energy", extending the time scale from 2030 to 2050, and seeking a national energy transition in the long term, which relates to this study.

\subsection{Taiwan's Efforts to Implement SDGs and the Highlights of This Study}

As it has progressed into a developed country, Taiwan has made the UN SDGs an important foundational basis for its policymaking. Beginning in 2015, the Executive Yuan's National Council for Sustainable Development has held a series of "Sustainable Development Goals Review Research Meetings", setting clear development and completion times for the SDGs [13,14]. In November 2016 at the 29th meeting of the Executive Yuan's National Council for Sustainable Development, a resolution was passed agreeing to Taiwan's participation in the UN SDGs; the Taiwanese SDGs were established, and a draft was announced, including the proportion of household access to power supply, the electricity generated by clean fuel, and the electricity generated by renewable energy as measurable SDG7 indicators [15]. As Taiwan is currently in the process of an energy transition, there is also a great need to implement reforms related to associated policy and legislation. According to Taiwan's Power Company statistics, in 2018, the percentage of electricity in Taiwan generated by renewable energy, including electricity generated by hydroelectricity power, only accounted for $4.9 \%$ of the total electricity generated, with fossil fuels accounting for $82.2 \%$ and the electricity generated by nuclear power accounting for $11.4 \%$ [16]. These statistics show that greater efforts still need to be made towards increasing renewable energy and carrying out a transition in the electricity structure. This effort of policymakers is not only needed in terms of changes to the electricity structure, as energy transition in 
Taiwan faces both vertical international pressure to reduce carbon emissions, and horizontal pressures from domestic energy democracy, with energy carbon emissions, industry transition and air pollution forming a triple helix of challenges. Changes in the use of high carbon emission fossil energy, as well as adjustments to high energy consumption and high air pollution industries, are related to the international and domestic demands for a reduction in carbon dioxide and air pollution $[17,18]$. Transitioning from fossil fuel to clean forms of energy and low carbon electricity is an important method to resolve the dialectical problems of this spiral-entangled triple helix, as low carbon electricity also produces lower levels of air pollution and $\mathrm{CO}_{2}$. When the International Energy Agency (IEA) [19] first proposed a market structure analysis report for a low carbon electricity system, the report referred to the environmental regulation of carbon pricing, electricity taxation and de-carbonization as being an important direction for the international energy transition in the post-Paris Treaty climate. Moreover, Fouquet [20] noted that some countries, through institutions, have been able to increase their speed of energy transitions and their use of low pollution energy. Taiwan has made "The Amendment of Electricity Act" into an institutional tool for energy transition to enable electricity industry reforms, as well as to break the monopoly of the electricity market. Among critical reviews of the new Electricity Act in Taiwan, the study of Gao et al. [21] focused on the Taiwanese electricity sector's liberalization and introduced other countries' approaches to energy transition using an inductive method. Going beyond the study of Gao et al. [21], with a concentration on renewable energy development, the main purpose of the present study is to establish an analytical structure with diverse and sustainable perspectives, derived from energy theory and the UN SDGs, to theorize the national energy transition, and to provide empirical Taiwanese evidence in a social context by holding six focus group forums. There are five main areas of significance or foci to this study: (1) the national energy transition in response to the UN SDGs; (2) a transition analytical structure derived from energy theory; (3) evidence of the challenges for national energy transition seen in the current reforms of Taiwan's electricity sector; (4) laws related to the electricity sector acting as legal tools for national energy transition; (5) the concepts that every country should use methods in line with their own local conditions to develop a policy bundle and move toward an energy transition. The main contributions of this study to the existing literature are explained as follows: (1) this pioneering study correlates the national energy transition with SDG7 by adopting energy theory and conducting legal studies. (2) The national energy transition framework features generalized knowledge, deducted from energy justice theory and energy management principles, and this study also provides practicable evidence through case studies of Taiwan and Japan. (3) Energy justice theory is too abstract to be applied, but this study establishes an applicable analytical framework using components from this theory, along with its path, to fill the knowledge gap between theory and practice or the policy gap between ambitious SDGs and their concrete indicators. (4) Outside the particular Taiwanese contexts, this study demonstrates that other countries, like Japan, can adopt a generalized energy transition framework. Regardless of Taiwan and Japan, other nations can develop their own national frameworks to diagnose their energy transition status and to focus on different components or paths in the framework. (5) Dioha and Kumar [22] innovatively studied SDG7's effects, especially on the residential sector, via a quantitative analysis. However, in the present study, the national energy transition, which we approach via a qualitative analysis, is cross-sectional, and a national pathway is necessary to promote sustainable energy comprehensively and efficiently. (6) Marcillo-Delgado et al. [23] adopted a quantitative analysis of electricity access, which is one of the SDG7 indicators and is an aspect of stable supply. Based on stable supply achieved through a path with a diverse supply with renewable energy, Korkovelos et al. [24] provided electrification modelling to support SDG7. However, based on the analytic framework of this study, the energy transition framework could be assumed to consider the comprehension and efficiency of balancing a stable supply, as well as other aspects, such as environmental protection, fair competition, and energy democracy.

The paper proceeds as follows: Section 2 presents preliminary findings on the implications of SDGs for national energy transition and a legal tool to promote the energy transition in Taiwan. Section 3 
outlines energy theory. Section 4 mainly presents the methodology and analytical framework. Section 5 compares the status of energy transition between Taiwan and Japan and presents a generalized national energy transition framework with a path through deduction, from energy theory to implementation. Finally, Section 6 offers our conclusions.

\section{This Study}

\subsection{Preliminary Findings on the Relationships Between SDGs and National Energy Transition}

The 2030 agenda for Sustainable Development has significant implications when it comes to energy transition (Table 1), with the main goal of SDG7 primarily pursuing the development of sustainable energy and the implementation of an energy transition at the national level [22,25-28]. SDG7 involves building a vision for developing sustainable energy and an energy transition, as well as a new agenda for sustainable energy services, with the aim to steadily provide the public affordable and clean energy or electricity. From this perspective, SDG7 is interrelated with the other goals in the agenda, with SDG8 working towards the goal of decent work and economic growth by focusing on the development of the social economy, such as by increasing energy-related research and development funding and human resources, in order to improve energy use efficiency. SDG9 aims at fostering innovation to promote industrial transition, while at the same time achieving energy efficiency. Like SDG8, this goal is focused on the economic aspect of development, but it is not clear how global energy transition will affect national labor markets [29]. SDG11 is aimed at the development of a sustainable city, there are also energy implications for this goal in terms of improving energy efficiency. Finally, SDG13 focuses on climate change and, according to Sachs et al., [30] the measurable indicators of average $\mathrm{CO}_{2}$ emissions are the consequences of energy carbon emission, with environmental pollution issues related to high carbon emissions being found in the energy sector, energy industry and high energy consumption, which, in turn, means focusing on the aspect of environmental protection.

Table 1. The meaning of energy and its indicators in the 2030 Agenda for Sustainable Development.

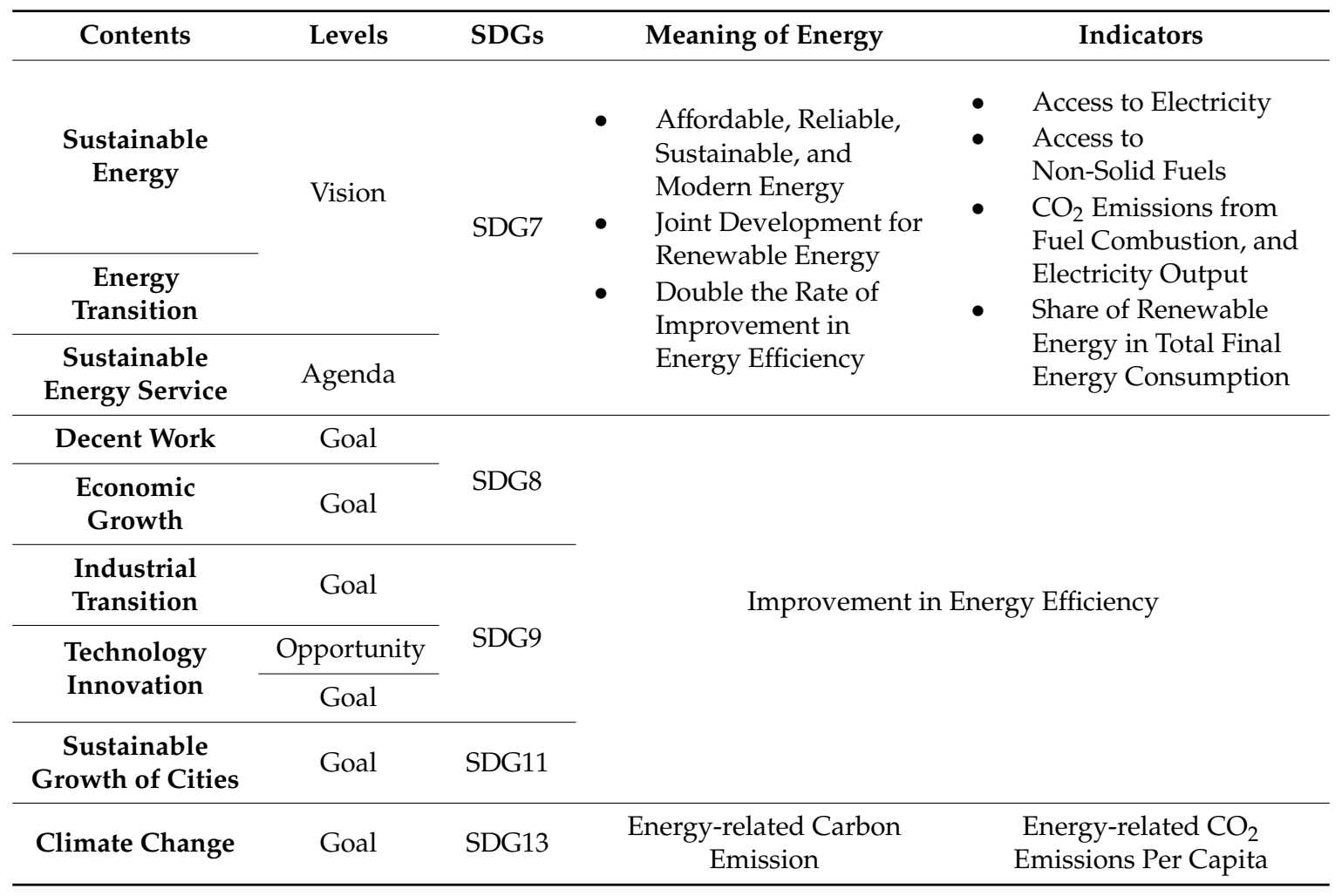




\subsection{New Electricity Act to Implement SDG7 and Promote the National Energy Transition}

Taiwan is currently in the early stages of promoting sustainable energy development and needs reforms in both policymaking and legislature, in order to break past its path dependence and construct innovative energy transition mechanisms. This study integrates the trends outlined by the UN SDGs and examines Taiwan's reforms of the Electricity Act and other complementary measures to inspect energy transition. In 2017, the Taiwanese government's amendments to the National Energy Policy, as well as the Electricity Act, revealed a double axis of policymaking and legal reforms, in turn driving the promotion of sustainable energy development. The above developments can be seen as important moments in the concretization of SDG7.

Besides examining an amended draft of the Electricity Act, this paper also adopts an energy justice and energy management perspective to develop related research, thereby carrying out empirical research based on a comprehensive overview of all of the policies related to energy transition or the development of renewable energy. Based on a previous adoption of Section 3.1 "Energy Theory and the Taiwan Status", this study adopts a definition of "energy justice" as "a global energy system that fairly disseminates both the benefits and costs of energy services, and one that has representative and impartial energy decision-making" [7], as well as a "definition of energy management" as a "forward-looking, organized and systematic coordination of energy procurement, conversion, distribution and utilization in order to cover requirements whilst taking into consideration ecological and economic objectives" [31]. That is to say, by an analytical structure for analyzing energy transition, while also carrying out an empirical study of Taiwan's practical transition experience, this study is able to dissect and identify the elements lacking in the current national energy transition policy and the driving force for energy transition, while, in turn, providing a reference for international comparisons.

\section{Energy Theory and Taiwan's Status}

\subsection{Energy Justice and Its Challenges in Taiwan}

The core implication of energy justice [32-35] lie in the recognition justice of energy development $[9,10]$, the procedural justice of energy democracy $[7,8]$, and the distributive justice of energy risk [36-38], which takes further steps to structuralize energy justice, using an analysis of other countries' domestic energy development situations, as well as discussing their suitability. Fan [39] discussed the overall international perspective on energy justice, noting that, internationally, there is an emphasis on discussions of fuel poverty, and that this notion of fuel poverty relates to issues of distributive justice and environmental justice. Therefore, the three core concepts of "energy justice" are "recognition justice, procedural justice and distributive justice". Based on a preliminary review, Taiwan's government has yet to integrate recognition justice in a way that provides a fully open and friendly environment for either natural or legal persons to operate electricity-generating enterprises. As a result, there is yet to be a recognition of public self-powered power generation or the right to buy, sell or dispose of electricity. In terms of procedural justice, there is a need for the government to adhere to legal due process in the formulation of policies, plans, individual cases, or development plans, including the opening of the policymaking process to public participation. For example, besides the formulation of policy, legally speaking, an environmental impact assessment should be carried out in order to enable the public to participate earlier in the process [40]. Quitzow et al. [41] described how, in the case of Germany's energy transition, there has not only been the development of renewable energy technology, the implementation of electricity feed-in tariffs, and the covering of related costs, but also a model of public participation and process of such developments, a fact that has earned itself attention in its own right in a climate where the impact of many countries' energy policies has produced social and economic change accompanied by tension and conflict.

Distributive justice could extend its influence to simultaneously address the social injustice of energy subsidies and energy poverty to bring about greater social equity [42,43]. Firstly, in terms of the social injustice of energy subsidies, in 2013, the Taiwan Control Yuan [44] noted that civilians having to 
fund subsidies for industrial-use electricity was unreasonable and demanded that the economic sector and the Taiwan Power Company (TaiPower Company) review this policy. Furthermore, in relation to the issues of social equity and energy poverty, the Department of Energy and Climate Change, UK, beginning in 2010, released its first Annual Fuel Poverty Statistics Report, which showed the statistics related to fuel poverty [45]. Moreover, the Health and Public Services Committee of London Assembly redefined fuel poverty [46]. Furthermore, the delineation of South Korea's energy poverty line must be taken into account in assessments of governmental energy welfare policies [47]. In conclusion, the issue of distributive justice is not limited to public services, but also relates to energy subsidies, fuel poverty and other energy-related welfare policies.

\subsection{Energy Management and Its Challenges in Taiwan}

Energy management is multifaceted, and there must be a mediation of the conflicts that are produced between its various facets. Liou [48] organized the theory and practical opinions on this subject from various countries and, based on this information, developed energy management principles including stable supply, fair competition and environmental protection.

In terms of stable supply, Taiwan has low energy self-sufficiency, and lacks energy autonomy, with its energy security being affected by Taiwan's diplomatic relations and energy value. The energy supply is affected by the technological ability or system integration of electricity generation, transmission, and distribution; therefore, these factors are addressed in the Bureau of Energy's Electricity Act. The Bureau of Energy [49] announced that a stable supply of electricity is the premise for promoting energy transition and electricity reforms, including opening electricity-generating enterprises and electricity-retailing enterprises to market competition, allowing consumer plants the free purchase of electricity and promoting the localization and decentralization of electricity use to improve the operational efficiency of electricity enterprises, to increase user rights and to create an electricity development environment that is decentralization friendly.

The root cause of unfair competition relates to whether the environmental costs are internalized for nuclear power, thermal-generated electricity, and renewable energy. In response to its problem of insufficient power supply, in 1995, Taiwan gradually opened up its market to independent power producer (IPPs) and signed 25-year contracts with them. Altogether, there are nine IPPs, all of which feature coal-fired or gas-fired power plants [50]. The establishment of these IPPs meant an end to the TaiPower Company's monopoly of the electricity generation industry. IPPs must negotiate their electricity prices with the TaiPower Company [51]. Even with the new Electricity Act's opening up of the electricity-generating market for renewable energy electricity-generating enterprises, the Green Citizens' Action Alliance, the Terminator of Nuclear Heresies and the Taiwan Youth Climate Coalition all questioned the decision to open up renewable energy-generated electricity to market competition for fear that this action would limit the development of renewable energy [52]. Opening up renewable energy-generated electricity to market competition could very easily result in obstructing the development of renewable energy, because the true cost of nuclear power and thermal-generated electricity has yet to be realistically internalized. As a result, traditional forms of energy and renewable energy are not yet on an equal footing and need management through environmental regulations to enable the internalization of the relevant environmental costs to become a reality, in turn promoting fair competition between electricity-generating enterprises.

From the perspective of environmental protection, Liou [53] studied the reduction of carbon dioxide emissions in Taiwan's electricity enterprises, proposing that Taiwan's carbon dioxide emissions currently account for $1 \%$ of the total world emissions, while, in 2013, the carbon dioxide emissions caused by Taiwan's electricity enterprises accounted for $58 \%$ of Taiwan's overall emissions. This study reviewed the legislation design related to reducing carbon dioxide emissions in electricity enterprises and provided relevant recommendations. Furthermore, the revisions made to the Electricity Act in terms of how it relates to environmental protection were focused on the internalization of external costs. However, the Environmental Protection Administration (EPA) expressed that, at the present time, there 
was no discussion of a stipulation for energy tax [54]. The EPA also studied and compared electricity enterprises' power generation equipment with that of renewable energy in terms of the Regulation of the Fund for the Development of Renewable Energy, proposing that this form of funding could replace energy taxes, while achieving the same function. In this way, future electricity generation enterprises could pay different amounts into the fund depending on the form of fossil fuel they use [55].

\section{Methodology, Analysis Structure, and Data}

\subsection{Methodology}

This study adopted textual analysis and legal policy analysis as its main form of research methodology. For textual analysis, this study analyzed papers and materials (please refer to Section 4.3, "Data"). For legal policy analysis, the following steps were taken: Firstly, we referenced the contents of each draft made of the revisions to the legislation [49,56-59], as well as the content of the recommendations made by the stakeholders at each public hearing [52]. Secondly, this study classified the contents of the drafts or revisions mentioned above to present the legal policy of the Electricity Act. This study's analytical structure also made use of legislative policy to analyze current challenges within the national energy transition. Moreover, this study attempted to organize related theories, and use them to deconstruct the complex content of the revisions to the Electricity Act, as well as legislative policy, developing a discourse for reforms and liberalization of electricity enterprises. For example, energy theory and Taiwan's status were used to summarize the role of energy justice and energy management discourse, which relate to the challenges Taiwan currently faces, in turn incorporating theoretical implications as a default aim of revision and adopting the systematic foundational principles and analytical structure of the national energy transition in order to discuss the related problems or the aims of the revisions to the Electricity Act. Finally, this study compiled information for a follow-up policy evaluation of the Electricity Act amendments to fulfill the requirements of these theoretical elements.

\subsection{Energy Transition Analysis Structure}

In order to provide a complete analysis structure for the amendments being made to the Electricity Act, this study attempted to fuse various theories and the components of energy management and energy justice with the development goals cited in Taiwan's Policy Guidelines for Energy Development, in order to organize them into an energy transition analysis structure (Figure 1). The outside half circle in Figure 1 represents the three components of the principles of energy management. The components in the circle were arranged in temporal order in the preliminary stage of this study, but the connected paths between these components are justified later and shown in Figure 2. In more detail (Figure 1), the theory for energy justice is connected with the principles for energy management, which are based on the same contents of "Fair Competition" and recognition of "Energy Development and Poverty" as it correlates with "Environment Protection". That is to say, the concept of energy transition proposed in this study fuses national energy development policy goals and combines them with environmental sustainability, the green economy, and the concepts of sustainability, and social equity. This kind of analysis structure agrees with the international trend established by the UN SDGs. Moreover, the main legal foci of this study are the revisions made to the Electricity Act; the Electricity Act itself is the key component, with other policies arranged accordingly. In terms of research methodology, this study considered the legislation before and after the 2017 amendments to the Electricity Act. We adopted a national energy transition analysis structure, alongside the legislative policy (after revisions), to dissect the current status and challenges facing Taiwan's energy transition. Finally, we interrogated the revision process and situation after the revisions were completed to be able to identify legislation and policies that support the 2017 new Electricity Act, in order to promote a national energy transition policy bundle. 


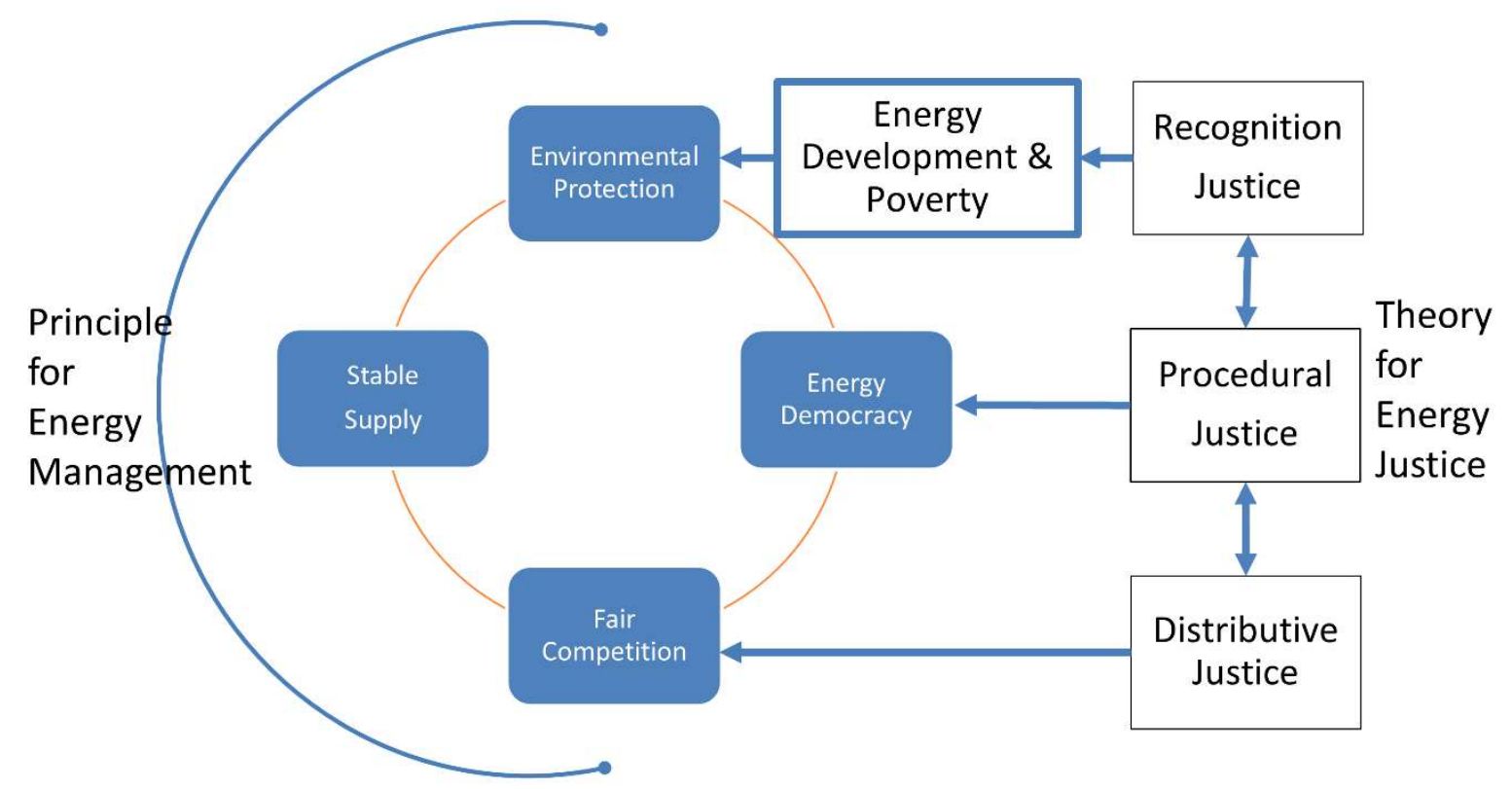

Figure 1. Analytical framework for national energy transition.

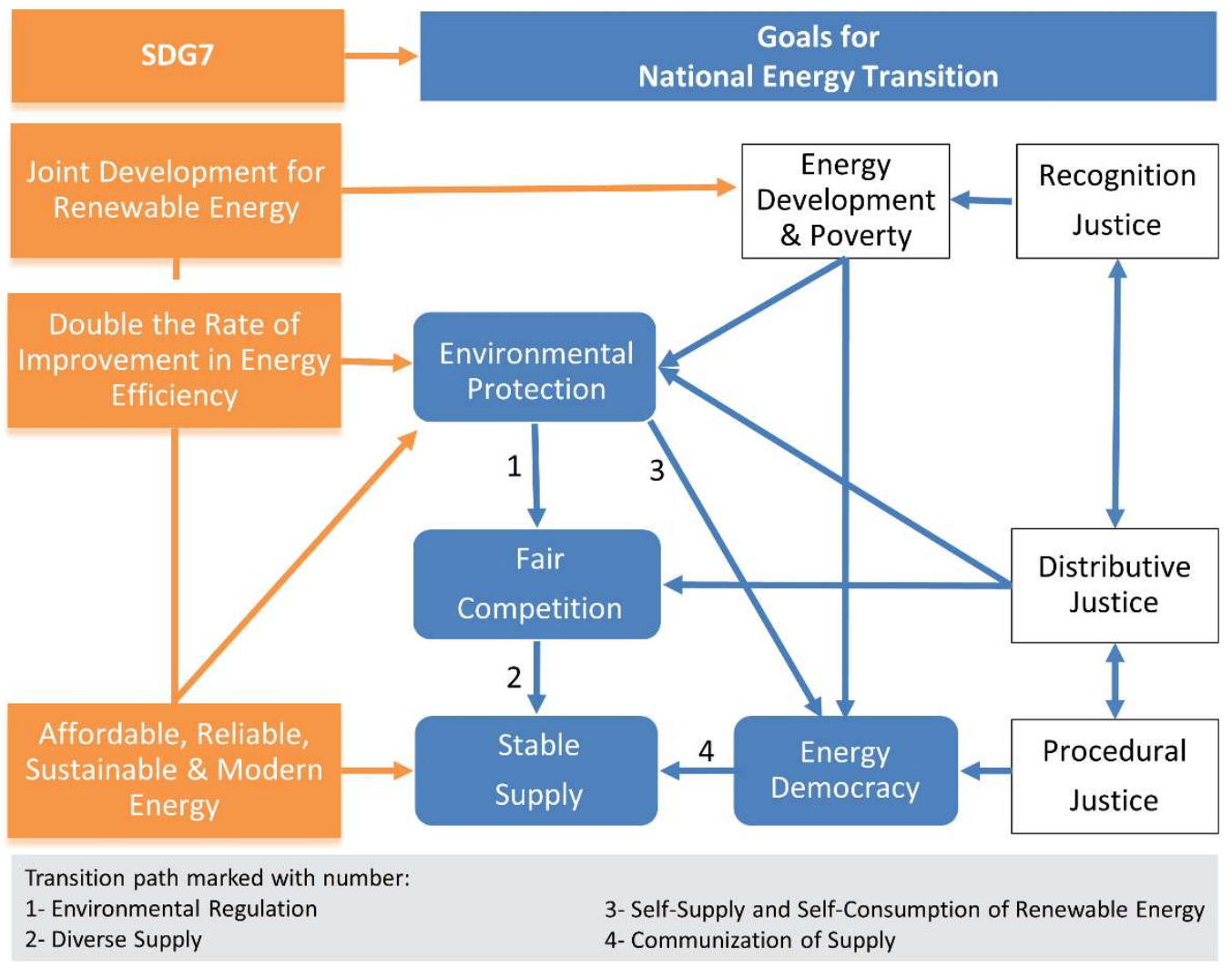

Figure 2. Response to Sustainable Development Goals (SDGs) with the national energy transition framework and path.

\subsection{Data}

The texts analyzed for this study not only included national energy policies, national energy laws, the Bureau of Energy's meeting minutes and the focus group's forum transcript, but also periodicals, books and other articles, civil group statements, media reports, and so on. The studied national energy policies include the Policy Guidelines for Sustainable Energy, Policy Guidelines for Energy 
Development, and the New Energy Policy. National energy laws included the Basic Environment Act, the Greenhouse Gas Reduction and Management Act, and the Renewable Energy Development Act. The focus group held six forums, attended by 45 people comprised of stakeholders in the revisions to the Electricity Act, academics and experts. Attendees included Bureau of Energy officials and thinktanks (administrative offices), the TaiPower Company (a single integrated electricity enterprise), a government-owned electricity enterprise, a renewable energy-based electricity-generating enterprise (Energy Cooperatives), social enterprises, legislators or administrator officers (Legislative Yuan), energy technology service industries, academic experts and environmental groups, IPPs, electricity consumers, and self-use power generator equipment users. This focus group, besides recognizing stakeholders, was able to produce an early assessment of the effects of the bill on those stakeholders, thereby aiding legal development and policy analysis. In relation to the UN SDGs, the textual analysis in this paper also included minutes from the National Council for Sustainable Development [13-15] meetings and press releases; in terms of the distributive injustice of energy poverty [42,43], this paper mainly focuses on a textual analysis of the Taiwan Control Yuan Survey report in 2013 [44].

\section{Results and Discussion}

\subsection{The Main Revision to the Electricity Act and Its Policy Analysis}

By analyzing the revisions made to the Electricity Act, we explored whether these revisions have the ability to drive energy transition, while also considering the policy packages that support this process. The newly passed revised version of the Act is more conservative than the ruling party or the "original" Executive Yuan version, adopting a go-ahead for the Green Energy two-stage revision policy. Currently, the most important aspects of the first stage of revisions to this Act are the liberalization of green electricity, involving the opening of the electricity market to renewable energy-generated enterprises. These electricity-generating enterprises should be able to distribute electricity to or buy and sell electricity directly from the end consumer. In order to prevent thermal power plants from monopolizing the market, the market has only been opened up to electricity-generating enterprises of renewable energy, implementing direct supply and self-consumption, or through electricity transmission and distribution enterprises, implementing the sale of electricity. Other main aspects of these revisions include the resource-sharing of the electricity grid and the establishment of an electricity control mechanism. As a singular integrated electricity enterprise or government-owned electricity enterprise, the TaiPower Company should establish subsidiary companies under the parent holding company to manage the generation of electricity, the distribution of electricity and electricity sales. According to a 2017 report by the Executive Yuan, the right of liberalization will be granted to other traditional thermal power plants only during the second stage of the revisions to the Act at some point in the future.

Under this structure, the new Electricity Act has yet to strengthen environmental regulations to ensure a transition away from high carbon electricity enterprises, which makes it difficult to promote healthy competition between traditional electricity-generating enterprises and renewable energy generators. Internationally, the Intergovernmental Panel on Climate Change (IPCC)'s Emissions Factor mainly uses carbon emission controls in electricity-generating enterprises, in particular, adopting source controls for carbon emissions in electricity enterprises to control electricity-generating enterprises and the carbon emissions released in the production process [59]. In contrast, an environmental regulation tool called the "Electricity Emission Factor" was adopted in Taiwan's newest revised version of the Electricity Act and was adapted from the IPCC's "Electricity Carbon Emission Factor". However, this factor only attempts to introduce controls for electricity-retailing utility enterprises and fails to introduce controls for the levels of carbon emissions produced. Thus, rather than introducing controls for electricity enterprises' energy sources, Taiwan has, instead, introduced changes in the form of the end controls for electricity retailing enterprises. As a result, Taiwan's adoption of the electricity carbon emission factor has made public electricity-retailing utility enterprises work from the demand 
side and downstream from the electricity market, toward the supply side and upstream from the electricity market to reversely require electricity generation enterprises to supply a certain percentage of renewable energy to generate electricity. However, if the regulations for electricity retailing utility enterprises, according to the electricity carbon emission factors, are not stringent enough, it will be difficult for such carbon emission controls to work effectively.

\subsection{The New Electricity Act Is Not Enough to Create an Electricity Market}

The IEA stresses that the electricity market needs reviving through innovative system design and forward-looking environmental regulations [19]. However, Taiwan's newly revised version of the Electricity Act neglects the environmental protection aspect, persisting with a traditional energy fund payment method that places little burden on electricity generating enterprises, while having yet to formulate an energy tax act or give electricity-generating enterprises matching obligations. Moreover, while the new Electricity Act both opens up renewable energy-generating enterprises to direct supply and authorizes the wheeling of electricity, it fails to provide economic incentives or other incentives, thereby compelling renewable energy electricity-generating enterprises, energy cooperatives or social enterprises to sell wholesale to the state, with the subsidy costs being footed by the people, thus increasing the state's financial burden. With electricity prices yet to rise, and before competitive pricing is included in electricity generation costs, the only way for renewable energy to be developed is through government subsidies, which lack market mechanisms [60]. Although Taiwan has passed amendments to the Electricity Act, it is important to implement the development of the "Renewable Energy Certificate (REC)" or other market mechanisms, such as the certification of the exchange market with the carbon trading market to build an active exchange market.

\subsection{Taiwan's Energy Transition Framework in the New Electricity Act Era}

We used policy analysis of the Electricity Act to study the driving force behind, and the possible transition paths toward, achieving an energy transition and then analyzed whether each potential transition path would be strong, moderate, or weak. The following discussion focuses on Taiwan's national energy transition path, along with the way that the new Electricity Act works with legislative policy, by analyzing Taiwan's energy transition status in the new Electricity Act era (Table 2). This study also provides objectively quantitative data (Table 3) to support whether a transition path is strong, moderate, or weak. 
Table 2. Taiwan's energy transition framework and its inter-connected policy bundles in new era of the Electricity Act.

\begin{tabular}{|c|c|c|c|c|c|}
\hline $\begin{array}{l}\text { Key Points in the Revision of the } \\
\text { Electricity Act (2017) }\end{array}$ & Aspect & $\begin{array}{c}\text { Degree of Aspect } \\
\text { Development }\end{array}$ & Path & $\begin{array}{l}\text { Degree of Path } \\
\text { Development }\end{array}$ & Policy Bundle \\
\hline \multirow{2}{*}{$\begin{array}{c}\text { Electricity Carbon Emission Factor; } \\
\text { Legalized Agenda for Nuclear-Free } \\
\text { Homeland }\end{array}$} & \multirow{2}{*}{$\begin{array}{l}\text { Environment-al } \\
\text { Protection }\end{array}$} & \multirow[t]{2}{*}{ Weak } & $\begin{array}{l}\text { Environment-al } \\
\text { Regulation }\end{array}$ & Weak & $\begin{array}{c}\text { Policy Guidelines for Energy } \\
\text { Development (2017)/ } \\
\text { Energy White Paper (2018; Draft)/ } \\
\text { Energy Tax (on Planning) }\end{array}$ \\
\hline & & & $\begin{array}{l}\text { Distribution of } \\
\text { Interests and Risk }\end{array}$ & Weak & $\begin{array}{l}\text { REC (2017); Obligation for } \\
\text { Consumer Plant to Setup } \\
\text { Renewable Energy (2019) }\end{array}$ \\
\hline \multirow{2}{*}{$\begin{array}{l}\text { Electricity Industry Regulatory Authority; } \\
\text { Revolution in Electricity Enterprise; } \\
\text { Dispute Mediation Between Enterprises }\end{array}$} & \multirow{2}{*}{$\begin{array}{c}\text { Fair } \\
\text { Competition }\end{array}$} & \multirow{2}{*}{ Weak } & Diverse Supply & Moderate & \multirow{2}{*}{$\begin{array}{c}\text { The Second Revision of Electricity } \\
\text { Act } \\
\text { (An Unclear Policy) }\end{array}$} \\
\hline & & & Public Services & Weak & \\
\hline $\begin{array}{c}\text { Mechanism for the Stabilization of Pricing; } \\
\text { Obligation to Provide Backup Capacity; } \\
\text { Obligation for Electricity Retailing Utility } \\
\text { Enterprise to Supply }\end{array}$ & $\begin{array}{l}\text { Stable } \\
\text { Supply }\end{array}$ & Strong & Obligation to Supply & Strong & $\begin{array}{c}\text { Policy Guidelines for Energy } \\
\text { Development (2017)/ } \\
\text { Energy Security } \\
\text { (A Developing Goal) }\end{array}$ \\
\hline \multirow{2}{*}{$\begin{array}{l}\text { Flexible and Legalized Organization of } \\
\text { Electricity Enterprise }\end{array}$} & \multirow{2}{*}{$\begin{array}{c}\text { Energy } \\
\text { Democracy }\end{array}$} & \multirow[b]{2}{*}{ Weak } & $\begin{array}{l}\text { Communization of } \\
\text { Supply }\end{array}$ & Weak & \multirow{2}{*}{$\begin{array}{c}\text { Policy Guidelines for Energy } \\
\text { Development (2017)/ } \\
\text { Energy White Paper (2018; Draft) } \\
\text { Action plan for People's Power } \\
\text { Plant (2018; Draft) }\end{array}$} \\
\hline & & & $\begin{array}{l}\text { Self-Supply and } \\
\text { Self-Consumption of } \\
\text { Renewable Energy }\end{array}$ & Weak & \\
\hline
\end{tabular}


The influence of the 2017 amendment to the Electricity Act on Taiwan's energy transition is weak, as seen from the content of Table 2. From an analytical perspective of energy transition, besides being strong in stabilizing the supply side of development, other aspects of development are weak. In terms of path development, besides the electricity supply obligation path development being directly linked to the stable supply aspect (and, therefore, being strong), the fair competition aspect and the path development towards diversification of the related electricity supply is moderate, while other aspects linked to path development are all weak. Therefore, three quarters of the individual aspects of development are currently weak. However, among the various path developments, five out of seven are weak. Below is a clear explanation of the various aspects and paths:

(1) The stable supply aspect is strong because Taiwan's government has not only designed an electricity pricing stabilizing mechanism (which uses more than $15 \%$ of the electricity reserve capacity rate, mandated by the Regulation Governing Electricity Reserve Capacity originating in the 27th article of the Electricity Act), but it has also entrusted the obligation for supplying electricity to public retailing electricity enterprises. Moreover, the TaiPower Company [61] has launched a long-term Power Supply Development Plan extending from 2018 to 2028. Furthermore, Taiwan's Executive Yuan [62] reviewed the energy policy to confirm the percentage of more than $15 \%$ of the electricity reserve capacity rate after a referendum at the end of 2018 . As a result, the electricity supply obligation (path development) is strong. However, the path development of the diversification of electricity supply, owing to the fair competition aspect or the go-ahead policy for green energy, is moderate. Moreover, there is a lack of a driving force for the communization of supply (path development: weak) from the energy democracy aspect without the mechanism for supporting community power plants or people's power plants;

(2) The fair competition aspect is weak, as the reforms taking place in the electricity enterprises have yet to see sweeping changes, and the independency and transitional capacity building of the control mechanisms for electricity enterprises are not yet strong enough. Moreover, the environmental regulations applied to the electricity carbon emission factor have yet to apply source management to electricity enterprises, which, in turn, means that in areas related to environmental protection environmental regulations (path development) remain weak and are incapable of promoting the transition of electricity enterprises and other fair competition aspects;

(3) Developments in the area of environmental protection are weak, as Taiwan has yet to implement either a carbon trading or energy tax system. The environmental cost has also has yet to be suitably internationalized, which, in turn, affects the distributive justice of environmental risk [36,37], with a weak path development in the distribution of interests and risk. The Taiwanese government is in the process of working toward greater cooperation between the public and private sectors through the "Energy Transition's white paper (at plan's level under a policy)", which identifies the formulation of an energy tax as vitally important in enabling the public to participate in the agenda;

(4) The development of the environmental protection aspect is weak. Nevertheless, Taiwan began to implement the REC form of market subsidies in 2017, which have gradually replaced feed-in tariffs and enabled an improved distribution of interests. However, the market for RECs is still in its nascent stages, and the government is still in the process of establishing a more fully comprehensive market mechanism, which directly relates to weak path development in interest and risk distribution. Furthermore, the goal of a nuclear-free homeland was mandated to be reached by 2025 in the $95^{\text {th }}$ Article of the Electricity Act. Although the referendum in the end of 2018 resulted in the revocation of this article [63], the goal of the nuclear-free homeland is still mandated by the Basic Environment Act;

(5) The development of the energy democracy aspect is also weak. However, Taiwan was able to make the overall organization of electricity enterprises more flexible through the revisions made to the Electricity Act (i.e., the administrative authorities agreed to greater decentralization of energy management-for example, by allowing local government authorities to run private 
energy companies or energy cooperatives). However, due to the fact that the communization of the power supply (development aspect: weak) and the legal construction of the peoples power plants are both lacking, the principal recipients of the electricity feed-in tariff system are private enterprises with a certain level of capital rather than energy cooperatives aimed at developing the whole community, community power plants or social enterprises invested in by normal civilians.

Since the 2017, amendments to the Electricity Act have failed to provide a driving force for energy transition in Taiwan, there is a need for other support measures to be established alongside the Electricity Act, in order to develop a national energy transition policy bundle. Currently, in terms of policy packages, there has been a few areas of development, such as the new REC system brought into effect by the Taiwanese government in 2017, and attempts to allow the REC market subsidy system to work alongside state-funded feed-in tariffs in order to reduce the number of casualties of pollution from power generation or the amount of Taiwanese people's money spent on subsidy systems. Thus, the government's REC system offers a response to the problem of distributive injustice by giving consumer plants energy-rationing obligations. This makes it mandatory for consumer plants to be set up with renewable-energy-based power generation equipment. Furthermore, rather than making it compulsory to establish the equipment themselves, plants can purchase an REC as an alternative plan, enabling them to comply with the agreement of self-generation of power through the obligation to set up renewable-energy-based power generation equipment. In this way, Taiwan can avoid an increase in electricity prices caused by internalizing the environmental costs of traditional thermal-generated energy, while, at the same time, enabling market subsidies in the form of RECs to replace state subsidies in the form of feed-in tariffs [60].

\subsection{National Energy Transition Correlated with SDG7}

In terms of national energy development and poverty (Figure 2), a response to SDG7's proposal for "Renewable Energy Joint Development" can be seen in the concept of recognition justice $[9,10]$. Beginning with the recognition justice aspect of energy justice, the amendment made to the Electricity Act involves electricity retailing sales discounts for vulnerable parties, a concept that is part of the fuel poverty or energy poverty issue as a whole. At the same time, this recognizes that the public can be involved in generating and selling electricity not only through energy cooperatives but also through other electricity enterprise organizations. As a result, in the amendments made to the Electricity Act public participation in energy development or the installation of renewable-energy-based power generation equipment is recognized, while, in terms of renewable energy, the low cost of installing of solar-generated electricity or on-land wind-generated electricity means that the potential for mutual public participation in renewable energy development is higher. Although public mutual participation is possible, renewable energy development in Taiwan needs more stakeholder communication on the demand for land and encourages relevant energy development on rooftops prior to ground solar photovoltaic power. In Figure 2, this study frames SDGs seven, eight, nine, 11 and 13 alongside the correlation between national energy transition and energy justice. Therefore, the amendment to the Electricity Act not only relates to environmental protection, fair competition, stable supply and energy democracy (the four axes of energy development), but also closely connects and responds to the various aspects of the SDGs as well as the issues of recognition justice, distributive justice and procedural justice (which are connected to energy justice). In this way, we view the revised Electricity Act as an important step in the national energy transition and consider whether it conforms to the various important international SDG trends and energy justice, and if it adequately handles the demands of energy poverty.

One of the main legal tools in national energy transition is electricity sector laws. The amendments made to these laws embody the SDGs. The interim structural problems evident within the amendment to the Electricity Act point to the challenges facing Taiwan in this stage of national energy transition, including returning the right to generate electricity to the people, the limits of a two-stage process to amend the law and (green energy first, unbundling of the power and the grid, and the liberalization of 
electricity retailing), encourage fair competition, the externalization of environmental cost, the lack of environmental regulations to drive reforms in electricity generating enterprises, the weakening of electricity emission factor source management, interests and risk distribution, energy poverty, etc. On the one hand, these challenges fit with the core concepts of the SDG7 affordable energy issue; on the other hand, these challenges reflect the energy justice-related issues of recognition justice, distributive justice and procedural justice, and the other issues of energy democracy and energy poverty that extend from these problems. At the same time, these two main areas could be connected by taking an energy management perspective on environmental protection, fair competition, stable supply, and social justice.

Regarding the aspects of energy transition analyzed here (Table 2), this study assesses the SDG7 indicators (Table 1) with the following polices (more concrete quantitative values are showed in another form in Table 3). Firstly, the indicator of "Access to Electricity" is strongly connected with the development of a stable supply aspect and its path of "Obligation to Supply", which is mandated by the Electricity Act and by the policy bundle of "Policy Guidelines for Energy Development". Secondly, the indicators of "Access to Non-Solid Fuels" and " $\mathrm{CO}_{2}$ Emissions from Fuel Combustion and Electricity Output" are extremely relevant to the development of the environmental protection aspect and its path of "Environmental Regulation", with the policy bundle of "Electricity Carbon Emission Factor" and "Energy Tax". Furthermore, the indicator of "Share of Renewable Energy in Total Final Energy Consumption" is related to the development of the environmental protection aspect and its path of "Distribution of Interests and Risk", with the policy bundle of "Electricity Carbon Emission Factor", "REC", and "Obligation for Consumer Plant to Setup Renewable Energy" related to the development of the fair competition aspect and its path of "Diverse Supply", with the policy bundle of "Revolution in Electricity Enterprise" and "The Second Revision of Electricity Act", as well as to the development of the energy democracy aspect and its path of "Self-Supply and Self-Consumption of Renewable Energy", with the policy bundle of "Flexible and Legalized Organization of Electricity Enterprise", and "Action Plan for People's Power Plant". Therefore, with their policy tools, the key factors in the revision of the Electricity Act and the policy bundles (Table 2) pave clear paths toward the improvement of the SDGs and their indicators. In more detail (Figure 2), the strong development of a stable supply aspect will enhance SDG7's pursuit of "Affordable, Reliable, Sustainable, and Modern Energy" and its indicators. On the other hand, the weak development of the fair competition aspect will problematize directly promoting the development of a stable supply aspect, which will make it difficult to indirectly enhance SDG7 and its indicators.

\subsection{Comparison of National Energy Transition between Taiwan and Japan}

This study also compared the differences between the SDG7 relationships and the national energy transitions in Taiwan and Japan, based on the similar initiative of their Electricity Acts and policy bundles (Table 3). This study selected Japan because both Taiwan and Japan are island nations that suffer earthquakes, typhoons and a lack of energy reserves. After the Fukushima Nuclear Accident in 2011, the Japanese Government launched the "Policy on Electricity System Reform" (in 2013) and then revised its "Electricity Business Act". During the period from 2013 to 2015, Japan aimed to stabilize its power supply and lowered electricity prices, and promote the liberalization of its electricity distribution through the policy bundle of "Establishing Organization for Cross-Regional Coordination of Transmission Operators, Full Retail Competition, and Legal Unbundling of Transmission and Distribution Sectors, during the period from 2015 to 2020" [64,65]. This policy bundle for energy transition in Japan was mainly concentrated on fair competition and stable supply, which corresponds with the SDG7 goal of "affordable and reliable energy" and its indicator "access to energy". 
Table 3. A comparison of the seventh Sustainable Development Goal (SDG7) relationship and energy transition between Taiwan and Japan, based on the similar initiative of Electricity Act with policy bundles.

\begin{tabular}{|c|c|c|c|}
\hline SDG7 Relationship & Item & Taiwan & Japan \\
\hline $\begin{array}{l}\text { Energy Transition at the } \\
\text { National Level }\end{array}$ & Amendment & Electricity Act (2017) & Electricity Business Act (2013-2015) \\
\hline $\begin{array}{l}\text { Energy Transition at the } \\
\text { National Level }\end{array}$ & Energy Mix & $\begin{array}{c}\text { Electricity Demand }(+2 \% / \text { Year }) \\
\text { Nuclear } 12 \% \rightarrow 0 \%(-1 \% / \text { Year }) \\
\text { Renewable } 5 \% \rightarrow 20 \% \\
(+1 \% / \text { Year }) \\
\text { Coal- and Oil-fired } \\
50 \% \rightarrow 30 \%(-2 \% / \text { Year }) \\
\text { LNG-fired } 32 \% \rightarrow 50 \%(+2 \% / \text { Year }) \\
\text { (From Year } 2016 \text { to } 2025) \\
{[62,66]}\end{array}$ & $\begin{array}{c}\text { Electricity Demand }(+1 \% / \text { year }) \\
\text { Nuclear } 1 \% \rightarrow 20 \% \sim 22 \%(+2 \% / \text { Year }) \\
\text { Renewable } 10 \% \rightarrow 22-24 \%(+1 \% / \text { Year }) \\
\text { Coal- and Oil-fired } \\
65 \% \rightarrow 29 \%(-3 \% / \text { Year }) \\
\text { LNG-fired } 24 \% \rightarrow 27 \%(-0 \% / \text { Year }) \\
\text { (From Year } 2016 \text { to } 2030)[67]\end{array}$ \\
\hline \multirow{3}{*}{ Access to Electricity } & Status & $100 \%$ (2016) [68] & $100 \%$ (2016) [69] \\
\hline & \multirow{2}{*}{ Policy Bundle } & $\begin{array}{l}\text { Dividing into an Electricity } \\
\text { Transmission and Distribution } \\
\text { Enterprise (2023-2026) }\end{array}$ & $\begin{array}{l}\text { Establishing Organization for } \\
\text { Cross-Regional Coordination of } \\
\text { Transmission Operators (2015) }\end{array}$ \\
\hline & & $\begin{array}{l}\text { Obligation for Electricity } \\
\text { Retailing Utility Enterprise } \\
\text { to Supply (2017) }\end{array}$ & $\begin{array}{c}\text { Obligation for Electricity Retailing } \\
\text { Utility Enterprise } \\
\text { to Supply (2016) }\end{array}$ \\
\hline \multirow[b]{2}{*}{$\begin{array}{l}\text { Access to Non-Solid } \\
\text { Fuels }\end{array}$} & Status & $\begin{array}{l}\text { Electricity from Coal-fired } 46 \% \\
\text { (2016) [66] }\end{array}$ & $\begin{array}{l}\text { Electricity from Coal-fired 25\% } \\
\text { (2016) [67] }\end{array}$ \\
\hline & Policy Bundle & $\begin{array}{l}\text { Project Report of Energy Policy } \\
\text { Review for Response to the } \\
\text { Result of Referendum (2019)/ } \\
\text { National Energy Mix }\end{array}$ & $\begin{array}{c}\text { Retailing from } \\
\text { Non-fossil Fuels-based Power Ratio } \\
\text { (2016) }\end{array}$ \\
\hline \multirow{3}{*}{$\begin{array}{l}\mathrm{CO}_{2} \text { Emissions from } \\
\text { Fuel Combustion and } \\
\text { Electricity Output }\end{array}$} & Status & $\begin{array}{c}11.9 \text { t- } \mathrm{CO}_{2} \text { Per Capita (2015) } \\
{[70]}\end{array}$ & 9.9 t- $\mathrm{CO}_{2}$ Per Capita (2015) [70] \\
\hline & Plan & $\begin{array}{c}0.529 \mathrm{Kg}-\mathrm{CO}_{2} \text { Per } \mathrm{KWh} \rightarrow \\
0.394 \mathrm{Kg}-\mathrm{CO}_{2} \text { Per KWh } \\
(-3 \% / \text { Year }) \\
\text { (From Year 2016 to 2025) [71] }\end{array}$ & $\begin{array}{c}0.516 \mathrm{Kg}-\mathrm{CO}_{2} \text { Per } \mathrm{KWh} \rightarrow \\
0.370 \mathrm{Kg}-\mathrm{CO}_{2} \text { Per KWh } \\
(-2 \% / \text { Year }) \\
\text { (From Year } 2016 \text { to } 2030)[72,73]\end{array}$ \\
\hline & Policy Bundle & $\begin{array}{c}\text { Electricity } \\
\text { Carbon Emission Factor } \\
(2017)\end{array}$ & $\begin{array}{c}\text { Retailing from } \\
\text { Non-fossil Fuels-based Power Ratio } \\
\text { (2016) }\end{array}$ \\
\hline \multirow{3}{*}{$\begin{array}{l}\text { Share of Renewable } \\
\text { Energy in Total Final } \\
\text { Energy Consumption }\end{array}$} & Status & 5\% (2016) [66] & $10 \%(2016)[67]$ \\
\hline & \multirow[t]{2}{*}{ Policy Bundle } & $\begin{array}{l}\text { Project Report of Energy Policy } \\
\text { Review for Response to the } \\
\text { Result of Referendum (2019)/ } \\
\text { National Energy Mix }\end{array}$ & $\begin{array}{l}\text { Long-term Energy Supply and } \\
\text { Demand Outlook (2015)/ } \\
\text { National Energy Mix }\end{array}$ \\
\hline & & REC (2017) & $\begin{array}{c}\text { Non-Fossil Fuel Energy Certificate } \\
\text { Program (2018) }\end{array}$ \\
\hline
\end{tabular}

On the other hand, in 2015, the Japanese Government proposed a "Long-Term Energy Supply and Demand Outlook", to confirm its national energy portfolio in 2030 and to promote the development of renewable energy to account for more than $20 \%$ of all generated electricity [74], a response to the SDG7 meaning of "joint development for renewable energy" and its indicator of a "Share of Renewable Energy in Total Final Energy Consumption". Moreover, Taiwan and Japan have individually taken the increasing electricity demand and energy savings into a scenario analysis of energy transition $[62,67]$. Taiwan and Japan also have a common need to make more efforts in their environmental regulation for carbon reductions in the electricity sector, sharing similar policy bundles for creating a market of non-solid fuels via the "Electricity Carbon Emission Factor" in Taiwan and the "Retailing from 
Non-Fossil Fuels-Based Power Ratio 44\%" in Japan [75], to improve the SDG7 indicators of " $\mathrm{CO}_{2}$ Emissions from Fuel Combustion and Electricity Output" and "Access to Non-Solid Fuels".

In short, Taiwan and Japan have paid more attention to the SDG7 indicator of "Access to Electricity", with Japan opening full retail competition, albeit in name only and accompanied by the unfair issues of the unbundling of the transmission and distribution sectors, while neglecting the SDG7 indicator of " $\mathrm{CO}_{2}$ Emissions from Fuel Combustion and Electricity Output" by failing to implement more stringent environmental regulations or related policy bundles, as indicated in the form (Table 2). In particular, Taiwan faces more challenges on the issue of carbon reduction, with the goal of national energy mix by 2030 to replace nuclear power with renewable energy and to reduce coal-fired power by increasing liquefied natural gas (LNG)-fired power. Finally, following their goals and framework for national energy transition (Figure 2), Taiwan and Japan can strengthen their environmental regulations to promote fair competition directly, with fair competition then able to enhance stable electricity supply, thereby allowing these countries to move towards SDG7 and its indicators.

\section{Conclusions and Policy Implications}

The main problem explored in this study is how a nation should face the challenges of energy transition using legal tools or policy bundles. Responding to SDG7 and adopting a textual analysis of the law as its research methodology alongside legal policy analysis (during which a number of texts were analyzed), alongside the theories of energy justice and energy management, this study also established a national energy transition analysis structure, using Taiwan's amendments to the Electricity Act as a case study. The results of this analysis found that, for the legal reforms made to Taiwan's electricity sector, despite responding to the challenges in the early stages of national energy transition, as well as embodying many aspects of the SDGs, the majority of aspects or paths toward national energy transition are weak and need to be supported by other legislation and policies besides those within the electricity sector in order to achieve national energy transition and reach the SDGs. At the same time, this study also compares the SDG7 relationship and national energy transition between Taiwan and Japan, to justify the theoretical and analytical framework in this work.

Globally speaking, most countries like Taiwan are currently in a crucial period of energy transition. While facing pressure to reduce carbon emissions and air pollution, there is also the challenge of industry transitions; these challenges can all be approached using the structure shown in Figure 2 to ensure further resolution. Whether in the mature stages of energy transition (like Germany) or just starting out (like Taiwan, South Korea and Japan), all countries have responded to the SDGs' emphasis on energy justice, energy democracy and energy management and can be analyzed together. Countries that have just started out can particularly learn from a critical analysis of Taiwan's 2017 amendment to the Electricity Act and the weak driving force for energy transition that it has created. Here, we can observe a corresponding relationship-the more comprehensive the legislative revisions made to the electricity sector, the greater the influence not only on domestic issues of environment, society and the economy in terms of balanced development, but also on issues of international climate change, sustainable economy and social development responsibility.

Particularly worthy of a mention is the fact that, within the goals towards national energy transition, environmental protection involves energy competition, technological innovation, clean energy, energy interests and distributive justice issues that environmental health risks touch upon, which are at the core of the SDGs. This study provides an analytical structure for national energy transition, helping the country by outlining an energy transition agenda, including policy planning and the early stages of risk assessment for carrying out various transition goals or analytical aspects, with policy decisions made accordingly. Moreover, other countries that desire to implement this energy transition process can refer to the national energy transition goals discussed in this study, while, at the same, time taking an inventory of their domestic energy legislations or policies and looking at the different political, economic and social conditions unique to themselves, thereby adopting different legislation or policy bundles depending on the their unique local conditions in order to support or drive 
such energy transition paths. Furthermore, Renn et al. [76] proposed that sustainable development faces the issue of complex systems and that the science community could find solutions by identifying the pathways of these systems. This study responds to complex systems under the structure of SDG7 and its related goals, by establishing a national transition framework to identify the components, along with the path and the policy bundle, to balance national demands related to technology, the economy, society, and the environment. Finally, this study suggests two areas for future research, the first being comparison of the energy transition in Taiwan with the transitions of other countries, and the second to classify policy bundles into patterns to provide the other countries with references for policymaking. For policymakers, the approach of this study is beneficial not only by accurately diagnosing the status of the national energy transition, but also by efficiently concentrating on a particular component or path of the transition framework to strengthen or weaken related policy bundles based on particular national contexts and on a case-by-case basis. However, the approach of this study has limitations for policymakers, who will find it difficult to identify existing policies and implement related policies, due to the diversity of national policy contexts. This study, ultimately, has the following limitations: (1) beyond comparative case studies in Taiwan, Japan, or other east Asian countries, more national cases should be investigated based on this study to classify types of policy bundles in a particular component or path. (2) Exclusive of Table 3, this study did not focus on a quantitative analysis, as we aimed to develop a generalized analytic framework and to identify qualitative paths and policies among different components. (3) Using a quantitative analysis to study the paths between the components in the national energy transition framework has much greater potential than this study alone, such as using environmental regulation to promote fair competition via electricity carbon emission factors or implementing an energy tax, as mentioned in Table 2.

Author Contributions: Conceptualization, M.-X.L., H.M.L. and K.T.C.; methodology, M.-X.L., H.M.L and K.T.C.; formal analysis, H.M.L; investigation, M.-X.L.; resources, K.T.C.; data curation, M.-X.L.; writing-original draft preparation, M.-X.L.; writing-review and editing, M.-X.L. All authors have read and agreed to the published version of the manuscript.

Funding: This research received no external funding.

Conflicts of Interest: The authors declare no conflict of interest.

\section{References}

1. UN. Transforming our World: The 2030 Agenda for Sustainable Development. 2015. Available online: http://www.un.org/ga/search/view_doc.asp?symbol=A/RES/70/1\&Lang=E (accessed on 13 January 2020).

2. UN. The Sustainable Development Goals Report. 2016. Available online: http://www.un.org.lb/Library/ Assets/The-Sustainable-Development-Goals-Report-2016-Global.pdf (accessed on 13 January 2020).

3. International Bank for Reconstruction and Development; World Bank; IEA. Global Tracking Framework: Progress toward Sustainable Energy. 2017. Available online: http://www.worldbank.org/en/topic/energy/ publication/global-tracking-framework-2017 (accessed on 13 January 2020).

4. Osborn, D.; Cutter, A.; Ullah, F. Universal Sustainable Development Goals: Understanding the Transformational Challenge for Developed Countries; Report of a Study by Stakeholder Forum; Stakeholder Forum: Kent, UK, 2015.

5. Akinwale, Y.O.; Ogundari, I.O. Exploration of Renewable Energy Resources for Sustainable Development in Nigeria: A Study of the Federal Capital Territory. Int. J. Energy Econ. Policy 2017, 7, 240-246.

6. Munro, P.G.; Horst, G.V.D.; Healy, S. Energy justice for all? Rethinking Sustainable Development Goal 7 through struggles over traditional energy practices in Sierra Leone. Energy Policy 2017, 105, 635-641. [CrossRef]

7. Sovacool, B.K.; Dworkin, M.H. Energy justice: Conceptual insights and practical applications. Appl. Energy 2015, 142, 435-444. [CrossRef]

8. Walker, C.; Baxter, J. Procedural justice in Canadian wind energy development: A Comparison of Community-Based and Technocratic Siting Processes. Energy Res. Soc. Sci. 2017, 29, 160-169. [CrossRef]

9. Hernández, D. Sacrifice Along the Energy Continuum: A Call for Energy Justice. Environ. Justice 2015, 8, 151-156. [CrossRef] [PubMed] 
10. Bailey, I.; Darkal, H. (Not) Talking about Justice: Justice Self-Recognition and the Integration of Energy and Environmental-Social Justice into Renewable Energy Siting. Local Environ. 2018, 23, 335-351. [CrossRef]

11. International Institute for Applied Systems Analysis. Transformations to Achieve the Sustainable Development Goals. Report Prepared by the World in 2050 Initiative (TWI2050). 2018. Available online: www.twi2050.org (accessed on 13 January 2020).

12. UN. Launch of Report Transformations to Achieve the Sustainable Development Goals. 2018. Available online: http://www.iiasa.ac.at/web/home/research/twi/180712-TWI2050-report-launch.html (accessed on 13 January 2020).

13. National Council for Sustainable Development. The 27th Recording for Committee Meeting. 2015. Available online: http://nsdn.epa.gov.tw/Files/Meeting/27meeting.pdf (accessed on 6 June 2018).

14. National Council for Sustainable Development. News Press Release. 2017. Available online: https: //nsdn.epa.gov.tw/Nsdn_News.aspx?id=1306 (accessed on 13 January 2020).

15. National Council for Sustainable Development. The 39th Recording for Working Group Meeting. 2015. Available online: http://nsdn.epa.gov.tw/Files/WMeeting/39meeting.pdf (accessed on 6 June 2018).

16. TaiPower. Electricity Purchased by TaiPower Over the Years. 2020. Available online: https://www.taipower. com.tw/tc/Chart.aspx?mid=194 (accessed on 13 January 2020).

17. Chou, K.T. Challenge to Taiwan Energy Transition Driven by Climate Change. In Introduction to the Fourteen Lectures on Taiwan Energy Transition; Chou, K.T., Lin, Z.L., Eds.; Chuliu: Taipei, Taiwan, 2016.

18. Chou, K.T. Triple Helix Energy Transition Movement in Taiwan. In Energy Transition in East Asia: A Social Science Perspective; Chou, K.T., Ed.; Routledge: New York, NY, USA, 2018.

19. International Energy Agency. Re-Powering Markets: Market Design and Regulation during the Transition to Low-Carbon Power Systems; IEA: Paris, France, 2016.

20. Fouquet, R. Historical energy transitions: Speed; prices and system transformation. Energy Res. Soc. Sci. 2016, 22, 7-12. [CrossRef]

21. Gao, A.M.Z.; Fan, C.T.; Liao, C.N. Application of German Eenergy Ttransition in Taiwan: A Critical Review of Unique Electricity Liberalization as a Core Strategy to Achieve Renewable Energy Growth. Energy Policy 2018, 120, 644-654. [CrossRef]

22. Dioha, M.O.; Kumar, A. Exploring sustainable energy transitions in sub-Saharan Africa residential sector: The case of Nigeria. Renew. Sustain. Energy Rev. 2020, 117, 109510. [CrossRef]

23. Marcillo-Delgadoa, J.C.; Ortegob, M.I.; Pérez-Fogueta, A. A compositional Approach for Modelling SDG7 indicators: Case study Applied to Electricity Access. Renew. Sustain. Energy Rev. 2019, 107, 388-398. [CrossRef]

24. Korkovelos, A.; Khavari, B.; Sahlberg, A.; Howells, M.; Arderne, C. The Role of Open Access Data in Geospatial Electrification Planning and the Achievement of SDG7. An OnSSET-Based Case Study for Malawi. Energies 2019, 12, 1395. [CrossRef]

25. Hillerbrand, R. Why affordable clean energy is not enough. A capability perspective on the sustainable development goals. Sustainability 2018, 10, 2485. [CrossRef]

26. Acheampong, M.; Yu, Q.; Ertem, F.C.; Ebude, L.D.E.; Tanim, S.; Eduful, M.; Vaziri, M.; Ananga, E. Is Ghana Ready to Attain Sustainable Development Goal (SDG) Number 7? A Comprehensive Assessment of Its Renewable Energy Potential and Pitfalls. Energies 2019, 12, 408. [CrossRef]

27. Bhat, K.S.; Bachhiesl, U.; Feichtinger, G.; Stigler, H. A techno-economic model-based analysis of the renewable energy transition in the Indian subcontinent region. Elektrotech. Informationstechnik 2019, 136, 361-367. [CrossRef]

28. Santika, W.G.; Anisuzzaman, M.; Bahri, P.A.; Shafiullah, G.M.; Rupf, G.V.; Urmee, T. From goals to joules: A quantitative approach of interlinkages between energy and the Sustainable Development Goals. Energy Res. Soc. Sci. 2019, 50, 201-214. [CrossRef]

29. McCollum, D.L.; Echeverri, L.G.; Busch, S.; Pachauri, S.; Parkinson, S.; Rogelj, J.; Krey, V.; Minx, J.C.; Nilsson, M.; Stevance, A.S.; et al. Connecting the sustainable development goals by their energy inter-linkages. Environ. Res. Lett. 2018, 13, 033006. [CrossRef]

30. Sachs, J.; Schmidt-Traub, G.; Kroll, C.; Durand-Delacre, D.; Teksoz, K. SDG Index and Dashboards-Global Report; Bertelsmann Stiftung and Sustainable Development Solutions Network (SDSN): New York, NY, USA, 2016. 
31. The Association of German Engineers. VDI-Standard: VDI 4602 Part 2. 2013. Available online: https: //www.vdi.de/fileadmin/pages/vdi_de/redakteure/richtlinien/inhaltsverzeichnisse/1929951.pdf (accessed on 13 January 2020).

32. Goldthau, A.; Sovacool, B.K. The uniqueness of the energy security; justice; and governance problem. Energy Policy 2012, 41, 232-240. [CrossRef]

33. Heffron, R.J.; McCauley, D.; Sovacool, B.K. Resolving society's energy trilemma through the Energy Justice Metric. Energy Policy 2015, 87, 168-176. [CrossRef]

34. Jenskin, K.; Darren, M.; Raphael, H.; Hannes, S.; Robert, R. Energy justice: A Conceptual Review. Energy Res. Soc. Sci. 2016, 11, 174-182. [CrossRef]

35. Fuller, S.; McCauley, D. Framing Energy Justice: Perspectives from Activism and Advocacy. Energy Res. Soc. Sci. 2016, 11, 1-8. [CrossRef]

36. Jenkins, K.; McCauley, D.; Warren, C.R. Attributing Responsibility for Energy Justice: A case Study of the Hinkley Point Nuclear Complex. Energy Policy 2017, 108, 836-843. [CrossRef]

37. Damgaard, C.; McCauley, D.; Long, J. Assessing the Energy Justice Implications of Bioenergy Development in Nepal. Energy Sustain. Soc. 2017, 7, 1-16. [CrossRef]

38. Islara, M.; Brogaarda, S.; Lemberg-Pedersen, M. Feasibility of Energy Justice: Exploring National and Local Efforts for Energy Development in Nepal. Energy Policy 2017, 105, 668-676. [CrossRef]

39. Fan, M.F. The Issues of Justice on Low-Carbon Energy Transition. In Introduction to the Fourteen Lectures on Taiwan Energy Transition; Chou, K.T., Lin, Z.L., Eds.; Chuliu: Taipei, Taiwan, 2016.

40. Lin, M.X. Strategic Environmental Assessment on the Meaning of the Constitution. Tsinghua Discourses Rule Law 2012, 16, 136-150.

41. Quitzow, L.; Canzler, W.; Grundmann, P.; Leibenath, M.; Moss, T.; Rave, T. The German Energiewende What's happening? Introducing the special issue. Util. Policy 2016, 41, 163-171. [CrossRef]

42. Hiteva, R.P. Fuel poverty and vulnerability in the EU low-carbon transition: The case of renewable electricity. Local Environ. 2013, 18, 487-505. [CrossRef]

43. Bouzarovski, S.; Herrero, S.T.; Petrova, S.; Ürge-Vorsatz, D. Unpacking the spaces and politics of energy poverty: Path-dependencies; deprivation and fuel switching in post-communist Hungary. Local Environ. 2016, 21, 1151-1170. [CrossRef]

44. Control Yuan. Survey Report. 2013. Available online: http://www.cy.gov.tw/sp.asp?xdURL=./di/Message/ message_1.asp\&ctNode=903\&msg_id=4471 (accessed on 13 January 2020).

45. UK. Collection: Fuel Poverty Statistics. 2013. Available online: https://www.gov.uk/government/collections/ fuel-poverty-statistics (accessed on 13 January 2020).

46. London Assembly. In from the Cold? Tackling Fuel Poverty in London; Greater London Authority: London, UK, 2012.

47. Shin, J.S. Estimation of Fuel-Poverty in Korean Households. 2011. Available online: http://www.keei.re.kr/main.nsf/index_en.html?open\&p=\%2Fweb_keei\%2Fen_publish.nsf\%2Fby_report_ types\%2F985C6BB7B56C60C2492579AA001F60E4\&s=\%3FOpenDocument\%26menucode\%3DES173\% 26category\%3DResearch\%2520Papers (accessed on 13 January 2020).

48. Liou, H.M. Basic Principles and Legal Foundation of Energy Management: Post Kyoto Era. Nat. Taiwan Univ. Law J. 2006, 35, 45-102.

49. Bureau of Energy. Draft of Amendment to The Electricity Act. 2016. Available online: http://web3.moeaboe. gov.tw/ECW/populace/content/SubMenu.aspx?menu_id=3124 (accessed on 11 December 2018).

50. TaiPower. Status of Purchasing Electricity. 2016. Available online: https://www.taipower.com.tw/tc/page. aspx? $\mathrm{mid}=207 \& \mathrm{cid}=163 \& \mathrm{cchk}=9 \mathrm{c} 1 \mathrm{fa} 9 \mathrm{ec}-\mathrm{c} 80 \mathrm{e}-4 \mathrm{e} 08-\mathrm{b} 4 \mathrm{e} 8$-be1464b3811c (accessed on 13 January 2020).

51. Liou, H.M. Liberalization of electric Utilities and Competition Law: The Development in European Union; Germany and Taiwan. Chengchi Law Rev. 2002, 72, 65-139.

52. Bureau of Energy. Public Hearing for Draft of the Amendment to The Electricity Act: Video Recording from the 1st to 3rd Meeting. 2016. Available online: http://web3.moeaboe.gov.tw/ECW/populace/content/ SubMenu.aspx?menu_id=3124 (accessed on 11 December 2018).

53. Liou, H.M. Carbon Emission Reduction of Taiwan's Electric Power Industry. J. Adv. Clean Energy 2015, 2, 18-34.

54. Lin, S.H.; Lee, Y.Y. Currently No Plans to Discuss Energy Tax. 2016. Available online: http://www.chinatimes. com/newspapers/20160617000093-260202 (accessed on 13 January 2020).

55. Huang, L.Y. Pay to Energy Foundation/The Percentage from Renewable Energy Hopes Bring Down. 2016. Available online: http://www.cna.com.tw/news/afe/201607270469-1.aspx (accessed on 13 January 2020). 
56. DPP. Draft of the Amendment to the Electricity Act; Term 4th; Session 8th; and Conference 12th Legislative Yuan Bill Related Document: Legislator Proposal 660(15654); Legislative Yuan: Taipei, Taiwan, 2013.

57. Executive Yuan. Draft of the Amendment to the Electricity Act; Term 4th; Session 8th; and Conference 1st Legislative Yuan Bill Related Document: Legislator Proposal 660(15317); Legislative Yuan: Taipei, Taiwan, 2015.

58. Executive Yuan. The Electricity Act. Executive Yuan Gazette 23(21); Executive Yuan: Taipei, Taiwan, 2017.

59. IPCC NGGIP. Database on Greenhouse Gas Emission Factors (EFDB). 2017. Available online: http: //www.ipcc-nggip.iges.or.jp/EFDB/documents.php (accessed on 13 January 2020).

60. Lin, M.X. The Lost Segment of the Electricity Act? Scheme on Renewable Energy Certificates Connected with Renewable Portfolio Standard. 2017. Available online: http://www.storm.mg/article/241479 (accessed on 13 January 2020).

61. TaiPower. Long-termed Power Supply Development Plan. 2018. Available online: https://www.taipower.com.tw/upload/212/106\%E5\%B9\%B4\%E9\%95\%B7\%E6\%9C\%9F\%E9\%9B\%BB $\%$ E6\%

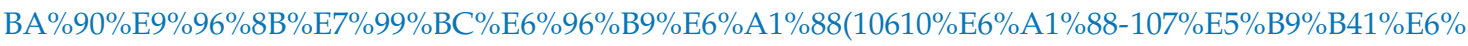
9C $\% 88 \% \mathrm{E} 4 \% \mathrm{BF} \% \mathrm{AE} \% \mathrm{E} 6 \% \mathrm{AD} \% \mathrm{~A} 3 \% \mathrm{E} 6 \% \mathrm{~A} 1 \% 88$ ).pdf (accessed on 13 January 2020).

62. Executive Yuan. Project Report of Energy Policy Review for Response to the Result of Referendum; Term 9th; Session 7th; and Conference 13st Legislative Yuan Bill Related Document: Legislator Proposal 887(16450); Legislative Yuan: Taipei, Taiwan, 2019.

63. Bureau of Energy. MOEA Announced that the Assessment Report on the Response to the Result of Energy Referendum. 2019. Available online: https://www.moea.gov.tw/MNS/populace/news/News.aspx?kind=1\& menu_id=40\&news_id=82760 (accessed on 4 March 2019).

64. Hiranuma, H. Japan's Energy Policy in a Post-3/11 World: Juggling Safety; Sustainability and Economics. 2014. Available online: https://www.tkfd.or.jp/en/research/detail.php?id=296 (accessed on 13 January 2020).

65. METI. Electricity Market Reform in Japan. 2015. Available online: https://www.meti.go.jp/english/policy/ energy_environment/electricity_system_reform/reference.html (accessed on 13 January 2020).

66. RSPRC. Interpreting 2016 Energy Trends in Taiwan. 2017. Available online: https://rsprc.ntu.edu.tw/zh-tw/ m01-3/energy-transformation/627-0330_tw-energy-status-2016 (accessed on 13 January 2020).

67. METI. Japan's Energy. 2018. Available online: https://www.enecho.meti.go.jp/en/category/brochures/pdf/ japan_energy_2017.pdf (accessed on 13 January 2020).

68. TaiPower. Taiwan Power Company Sustainability Report. 2017. Available online: https://www.taipower. com.tw/upload/85/2018011009015371352.pdf (accessed on 13 January 2020).

69. World Bank Group. Regulatory Indicators for Sustainable Energy; RISE, 2017. Available online: https: //rise.esmap.org/country/japan (accessed on 13 January 2020).

70. EC. $\mathrm{CO}_{2}$ Time Series 1990-2015 Per Capita for World Countries. 2017. Available online: https://edgar.jrc.ec. europa.eu/overview.php?v=CO2ts_pc1990-2015 (accessed on 13 January 2020).

71. Executive Yuan. Report for Energy Policy. 2018. Available online: https://www.ey.gov.tw/File/ FA89BE915504DBD8/311ed920-9788-499d-87ff-7d665b870a77?A=C (accessed on 13 January 2020).

72. FEPC (Federation of Electric Power Companies). Establishment of the Electricity Business Council for a Low-Carbon Society. 2016. Available online: http://www.fepc.or.jp/about_us/pr/pdf/kaiken_s_e_20160219. pdf (accessed on 13 January 2020).

73. ELCS (Council for a Low Carbon Society). $\mathrm{CO}_{2}$ Emission in 2017. 2018. Available online: https://e-lcs.jp/ news/detail/000048.html (accessed on 13 January 2020).

74. METI. Long-term Energy Supply and Demand Outlook. 2015. Available online: https://www.meti.go.jp/ english/press/2015/0716_01.html (accessed on 13 January 2020).

75. Nee, M.T.; Lin, M.X.; Liou, H.M.; Chou, K.T. A Comparative Study of the Carbon Emission Regulations between Taiwan's and Japan's Electricity Sectors. Sci. Technol. Law Rev. 2019, 31, 48-70.

76. Renn, O.; Chabay, I.; van der Leeuw, S.; Droy, S. Beyond the Indicators: Improving Science, Scholarship, Policy and Practice to Meet the Complex Challenges of Sustainability. Sustainability 2020, 12, 578. [CrossRef]

(C) 2020 by the authors. Licensee MDPI, Basel, Switzerland. This article is an open access article distributed under the terms and conditions of the Creative Commons Attribution (CC BY) license (http://creativecommons.org/licenses/by/4.0/). 